\title{
Changes in COVID-19 Knowledge, Beliefs, Behaviors, and Preparedness Among High-Risk Adults from the Onset to the Acceleration Phase of the US Outbreak
}

\author{
Stacy Cooper Bailey, PhD MPH' ${ }^{\top}$, Marina Serper, MD MS², Lauren Opsasnick, MS', \\ Stephen D. Persell, MD MPH', Rachel O'Conor, PhD MPH', Laura M. Curtis, MS', \\ Julia Yoshino Benavente, $M P H^{7}$, Guisselle Wismer, $M P H^{7}$, Stephanie Batio, $\mathrm{MS}^{7}$, \\ Morgan Eifler, $B S^{7}$, Pauline Zheng, $B A^{7}$, Andrea Russell, $\mathrm{MA}^{7}$, Marina Arvanitis, MD MPH', \\ Daniela P. Ladner, MD MPH ${ }^{3}$, Mary J. Kwasny, ScD4, Theresa Rowe, DO MS ${ }^{7}$, \\ Jeffrey A. Linder, $M D M P H^{7}$, and Michael S. Wolf, PhD MPH MA ${ }^{7}$
}

\begin{abstract}
'Division of General Internal Medicine \& Geriatrics, Feinberg School of Medicine at Northwestern University, 750 N. Lake Shore Drive, 10 th Floor, Chicago, IL, USA; ${ }^{2}$ Division of Gastroenterology and Hepatology, Leonard Davis Institute of Health Economics, University of Pennsylvania Perelman School of Medicine, Philadelphia, PA, USA; ${ }^{3}$ Northwestern University Transplant Outcomes Research Collaborative (NUTORC), Comprehensive Transplant Center, Feinberg School of Medicine at Northwestern University, Chicago, IL, USA; ${ }^{4}$ Department of Preventive Medicine, Feinberg School of Medicine at Northwestern University, Chicago, IL, USA.
\end{abstract}

BACKGROUND: The US outbreak of coronavirus disease 2019 (COVID-19) accelerated rapidly over a short time to become a public health crisis.

OBJECTIVE: To assess how high-risk adults' COVID-19 knowledge, beliefs, behaviors, and sense of preparedness changed from the onset of the US outbreak (March 13-20, 2020) to the acceleration phase (March 27-April 7, 2020). DESIGN: Longitudinal, two-wave telephone survey.

PARTICIPANTS: 588 predominately older adults with $\geq 1$ chronic condition recruited from 4 active, federally funded studies in Chicago.

MAIN MEASURES: Self-reported knowledge of COVID-19 symptoms and prevention, related beliefs, behaviors, and sense of preparedness.

KEY RESULTS: From the onset to the acceleration phase, participants increasingly perceived COVID-19 to be a serious public health threat, reported more changes to their daily routine and plans, and reported greater preparedness. The proportion of respondents who believed they were "not at all likely" to get the virus decreased slightly ( 24.9 to $22.4 \% ; p=0.04$ ), but there was no significant change in the proportion of those who were unable to accurately identify ways to prevent infection (29.2 to $25.7 \% ; p 0.14)$. In multivariable analyses, black adults and those with lower health literacy were more likely to report less perceived susceptibility to COVID-19 (black adults: relative risk (RR) 1.62, 95\% confidence interval (CI) 1.07-2.44, $p=0.02$; marginal health literacy: RR 1.96, 95\% CI 1.26-3.07, $p<0.01$ ). Individuals with low health literacy remained more likely to feel unprepared for the outbreak (RR 1.80, 95\% CI 1.11-2.92, $p=0.02$ ) and to express confidence in the federal government response (RR 2.11, 95\% CI 1.49-3.00, $p<0.001$ )

Prior Presentations None.

Received April 20, 2020

Accepted June 11, 2020

Published online September 1, 2020
CONCLUSIONS: Adults at higher risk for COVID-19 continue to lack critical knowledge about prevention. While participants reported greater changes to daily routines and plans, disparities continued to exist in perceived susceptibility to COVID-19 and in preparedness. Public health messaging to date may not be effectively reaching vulnerable communities.

KEY WORDS: COVID-19; knowledge; attitudes; behaviors; health literacy; comorbidity.

J Gen Intern Med 35(11):3285-92

DOI: $10.1007 / \mathrm{s} 11606-020-05980-2$

(c) Society of General Internal Medicine 2020

\section{INTRODUCTION}

The global outbreak of severe acute respiratory syndrome coronavirus 2 (SARS-CoV-2), the virus that causes coronavirus disease 2019 (COVID-19), has rapidly evolved into a worldwide public health crisis. In the uncertainty of this pandemic, effective public health messaging is needed to inform the US population of risks posed by COVID-19 and to motivate individuals, communities, and those in power to take action to minimize infection and prevent further spread of the virus. ${ }^{1}$ This need is particularly salient as recent data have revealed striking racial and ethnic disparities with COVID-19 infection and mortality., ${ }^{2}$ In Chicago, where black residents represent less than a third of the total population, they account for half of those who have tested positive for COVID-19 and two-thirds of those who have died. ${ }^{3}$ The success of the US response to this pandemic will depend largely upon the actions taken to protect and support the most vulnerable as well as how effectively public health information is conveyed to all Americans, particularly those at greatest risk of severe infection and death. ${ }^{1,4,5}$ 
Evidence has shown that how individuals obtain, interpret, and react to public health messages is influenced by socioeconomic, cultural, and health-related factors. ${ }^{6-8}$ To examine these influences within the context of the emerging coronavirus pandemic, our team previously conducted a telephone survey from March 13 to 20, 2020 among high-risk, predominately older adults living with one or more chronic conditions. ${ }^{9}$ We investigated participants' level of awareness and knowledge of COVID-19, their impressions of the seriousness of the pandemic, their perceived susceptibility to the virus, whether the outbreak was affecting their daily routine and plans, and how prepared they felt for the pandemic. At the onset of the US outbreak, we found that almost a third of respondents lacked critical knowledge of COVID-19 symptoms and methods of prevention. There were also marked disparities: individuals who were black, living in poverty, and/or with low health literacy were significantly less likely to believe they would become infected with COVID-19; they also reported feeling less prepared for an outbreak.

From March 20 to April 7, 2020, more than 350,000 Americans tested positive for the coronavirus and over 10,000 died. ${ }^{10}$ By April 7, 42 states had issued orders to close non-essential businesses and schools, restrict individual movement, and limit gatherings. ${ }^{11}$ An estimated 316 million Americans, 95\% of the US population, were living under "shelter in place" or similar orders to reduce transmission of the virus. ${ }^{11}$ Given this monumental shift in Americans' daily lives, the purpose of this investigation was to longitudinally examine how adults' COVID-19 knowledge, beliefs, behaviors, and sense of preparedness changed over time, from the onset to the acceleration phase of the US outbreak. We also explored psychosocial and sociodemographic factors influencing adults' beliefs surrounding COVID-19 as well as individuals' adoption of preventive behaviors.

\section{METHODS}

The Chicago COVID-19 Comorbidities (C3) Survey is a longitudinal, telephone-based study conducted among predominately older adults in Chicago, IL. ${ }^{9}$ We administered wave 1 of the survey at the onset of the US outbreak (March 13-20, 2020) and wave 2 during the acceleration phase of the pandemic (March 27-April 7, 2020). The Northwestern Institutional Review Board (IRB) approved the study procedures.

\section{Study Participants}

C3 participants were active enrollees in one of four ongoing, federally funded studies led by our team. Parent studies have been described in depth previously. ${ }^{9}{ }^{12-14}$ In brief, these studies included a longitudinal cohort study examining the cognitive function and aging among older adults and three randomized trials evaluating technology-based strategies to improve patient adherence to complex drug regimens. ${ }^{9,}{ }^{12-14}$ Participants were recruited into parent studies after receiving care from one of 5 academic or 2 community health centers in Chicago, IL.
The eligibility criteria for each study varied and have been described in detail. ${ }^{9}$ Overall, the target populations for these studies were older, English-speaking patients and those diagnosed with $\geq 1$ chronic condition; one trial also recruited Spanish-speaking adults. ${ }^{12}$ Only participants who provided consent to be contacted for future research opportunities and who completed a parent study interview from 2018 to 2020 were eligible to participate in wave 1 . A description of wave 1 methods has been published. ${ }^{9}$ All participants who completed wave 1 were eligible to participate in wave 2 .

\section{Data Collection Procedures}

Data collection was standardized across waves. Research staff contacted participants via telephone and invited them to complete a survey about COVID-19. Responses were recorded using REDCap. Surveys took $<20 \mathrm{~min}$ to complete and participants were offered a $\$ 10$ gift certificate per wave.

\section{Main Measures}

Participants completed standardized assessments of personal attributes as part of their participation in the NIH parent studies. This included items assessing sociodemographic (e.g., age, sex, race/ethnicity, income) and health characteristics (self-reported chronic conditions, overall health) as well as health literacy (the Newest Vital Sign) and health activation (Consumer Health Activation Index). ${ }^{15,} 16$ All assessments were administered, and results analyzed, according to published guidelines. ${ }^{15,16}$

COVID-19 Awareness, Perceived Seriousness, and Perceived Susceptibility. Awareness of COVID-19 was measured by asking participants whether they had heard of the coronavirus and, if so, if they knew someone who had or thought they had the virus. Perceived seriousness of COVID-19 was assessed by asking participants to rate, on a scale of 1 to 10 ( 1 being no threat at all and 10 being very serious), how serious a public health threat they believed the coronavirus is or might become. For perceived susceptibility, respondents were asked to rate the likelihood that they would get sick from the coronavirus (definitely will, probably will, it's possible, or not at all).

COVID-19 Knowledge. Knowledge of COVID-19 was assessed through two open-ended questions which asked participants to name 3 symptoms of the coronavirus and 3 actions they could take to prevent infection. Clinician raters independently coded verbatim responses as correct or incorrect. Participants were also asked to estimate the percentage of people who would die from the coronavirus once infected and the percentage of those who would have mild symptoms.

COVID-19 Reported Behaviors, Perceived Preparedness, and Confidence in Government. Participants were asked how much the coronavirus had changed their daily routine (a lot, some, a little, or not at all) and whether they had changed 
plans due to the virus. They also rated their confidence in the federal government's ability to prevent further COVID-19 outbreak (very confident, somewhat confident, not very confident, or not confident at all) and perceived preparedness for a widespread outbreak (very prepared, somewhat prepared, a little prepared, or not prepared at all).

\section{Analyses}

Descriptive statistics (means with standard deviations and percentage frequencies) were calculated for all patient characteristics and survey responses. Paired $t$ tests, ranked tests, and McNemar's tests were conducted to determine whether patient responses at waves 1 and 2 differed significantly. Associations between patient characteristics and responses to COVID-19 knowledge, beliefs, reported behaviors, and perceived preparedness items were evaluated in bivariate analyses using chi-square tests. Multivariable regression models were used to examine differences in outcomes; a Poisson distribution was used rather than odds ratios for the relative risk estimates. All models included health literacy, age, sex, race, poverty, number of days between waves 1 and 2 and parent study; this mirrored the models conducted for wave $1 .{ }^{9}$ In order to assess change between waves 1 and 2, generalized linear mixed models with a repeated effect were used to model interactions between wave and relevant covariates for each outcome. Least square means were then calculated for all covariates at wave 1 and 2 , and post hoc paired tests were conducted within each level of the covariate. All $p$ values from the paired tests were Bonferroni adjusted. Analyses were performed using SAS, version 9.4 (Cary, NC).

\section{KEY RESULTS}

Of the 630 participants in wave 1,11 declined to participate in wave 2, 29 could not be reached or asked to be contacted later, 2 had incomplete or missing data, and 588 completed the survey, for an overall cooperation rate of $93.3 \%$. The 42 adults who did not complete wave 2 were more likely to be black, to live below the poverty line, and to have low health literacy than those who participated. Table 1 summarizes participant characteristics for wave 2. Overall, patients were socioeconomically diverse, at an average of 62.4 years old, and $60.9 \%$ had $\geq 3$ chronic conditions.

\section{COVID-19 Awareness, Perceived Seriousness, and Perceived Susceptibility}

All participants had heard of the coronavirus and $27 \%$ said they knew of someone who had or thought they had the virus. Participants rated the coronavirus as a more serious public health threat in wave 2 than wave 1 (mean (SD) 8.9 (1.7) vs. 9.4 (1.3); $p<.001$; Table 2).

Almost a quarter (22.4\%) of participants at wave 2 believed they were "not at all" likely to get sick from the coronavirus
Table 1 Sample Characteristics $(n=588)$

\begin{tabular}{|c|c|}
\hline Variable & Summary value* \\
\hline Mean age (SD), $y$ & $62.4(11.0)$ \\
\hline \multicolumn{2}{|l|}{ Age group, $\%$} \\
\hline$<60$ years & 36.0 \\
\hline $60-69$ years & 36.6 \\
\hline$\geq 70$ years & 27.4 \\
\hline Female sex, $\%$ & 59.9 \\
\hline \multicolumn{2}{|l|}{ Racet, \% } \\
\hline Black & 31.2 \\
\hline White & 63.8 \\
\hline Other & 5.0 \\
\hline Hispanic, \% & 21.6 \\
\hline Limited English proficiency, \% & 11.4 \\
\hline Living below poverty levelt, $\%$ & 26.2 \\
\hline Married $\S, \%$ & 41.1 \\
\hline \multicolumn{2}{|l|}{ Health insurance, $\%$} \\
\hline Medicare & 16.7 \\
\hline Medicaid & 12.1 \\
\hline Private & 24.7 \\
\hline Medicare and private & 29.6 \\
\hline Medicare and Medicaid & 16.9 \\
\hline \multicolumn{2}{|l|}{ Care setting, \% } \\
\hline Academic & 69.0 \\
\hline Federally qualified health center & 31.0 \\
\hline \multicolumn{2}{|l|}{ Employment status, \% } \\
\hline Working for pay & 30.3 \\
\hline Not working (retired/unemployed) & 69.7 \\
\hline \multicolumn{2}{|l|}{ Health literacy, \% } \\
\hline Low & 23.0 \\
\hline Marginal & 23.6 \\
\hline Adequate & 53.4 \\
\hline Low health activation, $\%$ & 48.1 \\
\hline \multicolumn{2}{|l|}{ Number of chronic conditions, $\%$} \\
\hline 1 & 22.6 \\
\hline 2 & 16.5 \\
\hline$\geq 3$ & 60.9 \\
\hline 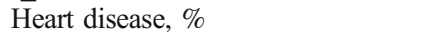 & 23.4 \\
\hline Pulmonary disease, $\%$ & 21.1 \\
\hline Diabetes (type 1 or 2 ), $\%$ & 47.0 \\
\hline Hypertension, \% & 64.8 \\
\hline Organ transplant recipient, $\%$ & 20.1 \\
\hline \multicolumn{2}{|l|}{ Self-reported overall health, $\%$} \\
\hline Excellent & 8.0 \\
\hline Very good & 29.4 \\
\hline Good & 41.0 \\
\hline Fair & 17.9 \\
\hline Poor & 3.7 \\
\hline
\end{tabular}

† Missing data for 22 participants

Missing data for 3 participants

\$Missing data for 53 participants

(Table 2). In bivariate analyses, individuals who were female, black, living below the poverty level, unemployed, and with low or marginal health literacy were more likely to believe that they were "not at all" likely to become infected (Table 3).

After multivariable adjustment, individuals who were black or had marginal health literacy skills were significantly more likely to state that it was "not likely" they would become sick (Table 4). This was similar to wave 1 , which found that adults who were black, living below the poverty line, and with low health literacy believed it was "not likely" they would become sick. ${ }^{9}$ While overall perceptions of susceptibility increased over time (Table 2), in multivariate analyses investigating change from wave 1 to wave 2 , no significant interaction between survey wave and any participant characteristic was found. This suggests there was no change in how certain groups, particularly by race, income, or health literacy, 
Table 2 Knowledge, Beliefs, Behaviors, and Perceived Preparedness for COVID-19 in Overall Sample

\begin{tabular}{|c|c|c|c|}
\hline \multirow[t]{2}{*}{ Item } & \multicolumn{2}{|c|}{ Summary Value } & \multirow[t]{2}{*}{$p$} \\
\hline & Wave 1 & Wave 2 & \\
\hline \multicolumn{4}{|l|}{ COVID-19 awareness, perceived seriousness, and susceptibility } \\
\hline $\begin{array}{l}\text { Mean response (SD) to: "On a scale of } 1 \text { to } 10 \text {, how serious of a public health threat do you think the coronavirus } \\
\text { is or might become? ( } 1 \text { being no threat at all, } 10 \text { being a very serious public health threat)" }\end{array}$ & $8.9(1.7)$ & $9.4(1.3)$ & $<0.001$ \\
\hline Do you think that you will get sick from the coronavirus? $(\%)$ & & & 0.04 \\
\hline I definitely will & 1.4 & 0.7 & \\
\hline I probably will & 8.1 & 12.4 & \\
\hline It's possible & 65.6 & 64.5 & \\
\hline Not at all & 24.9 & 22.4 & \\
\hline How likely do you think it is that you or someone you know may get sick from the coronavirus this year? (\%) & & & $<0.001$ \\
\hline Very likely & 21.2 & 20.4 & \\
\hline Somewhat likely & 44.7 & 54.7 & \\
\hline Not that likely & 23.7 & 20.2 & \\
\hline Not at all likely & 10.4 & 4.7 & \\
\hline \multicolumn{4}{|l|}{ COVID-19 knowledge } \\
\hline Mean response (SD) to: "What percentage of people who get the coronavirus do you think will die as a result?" $\dagger$ & $\begin{array}{l}14.0 \\
(19.3)\end{array}$ & $\begin{array}{l}15.5 \\
(20.6)\end{array}$ & 0.02 \\
\hline $\begin{array}{l}\text { Mean response (SD) to: "What percentage of people who get the coronavirus do you think will have only mild } \\
\text { symptoms?" }\end{array}$ & $\begin{array}{l}54.1 \\
(27.0)\end{array}$ & $\begin{array}{l}55.5 \\
(25.2)\end{array}$ & 0.41 \\
\hline Correctly identified 3 symptoms of the coronavirus (\%) & & & $<0.001$ \\
\hline 6. & 73.0 & 81.6 & \\
\hline No & 27.0 & 18.4 & \\
\hline Correctly identified 3 prevention methods of the coronavirus $(\%)$ & & & 0.14 \\
\hline Yes & 70.8 & 74.3 & \\
\hline No & 29.2 & 25.7 & \\
\hline \multicolumn{4}{|l|}{ COVID-19 reported behaviors } \\
\hline How much has the coronavirus changed your daily routine? $(\%)$ & & & $<0.001$ \\
\hline A lot & 58.8 & 73.0 & \\
\hline Some & 19.4 & 15.5 & \\
\hline A little & 14.3 & 9.5 & \\
\hline Not at all & 7.5 & 2.0 & \\
\hline Are you changing any plans that you have made because of the coronavirus? $(\%)$ & & & $<0.001$ \\
\hline Yes & 77.7 & 86.0 & \\
\hline No & 22.3 & 14.0 & \\
\hline I don't know & 0.0 & 0.0 & \\
\hline \multicolumn{4}{|l|}{ Confidence in federal government and perceived preparedness } \\
\hline How confident are you that the federal government can prevent further outbreak of the coronavirus?* $(\%)$ & & & 0.13 \\
\hline Very confident & 10.1 & 8.9 & \\
\hline Somewhat confident & 34.2 & 31.9 & \\
\hline Not very confident & 26.5 & 29.3 & \\
\hline Not confident at all & 29.2 & 29.9 & \\
\hline How prepared do you think you are for the widespread coronavirus outbreak?* $(\%)$ & & & $<0.001$ \\
\hline Very prepared & 21.3 & 27.3 & \\
\hline Somewhat prepared & 50.2 & 52.1 & \\
\hline A little prepared & 22.0 & 16.3 & \\
\hline Not prepared at all & 6.5 & 4.3 & \\
\hline
\end{tabular}

Questions re-worded at wave 2 to account for acceleration in the outbreak. At wave 1, questions were "How confident are you that the federal government can prevent a nationwide outbreak of the coronavirus?" and "How prepared do you think you are if there were to be a widespread coronavirus outbreak?"

COVID-19 coronavirus disease 2019

*Values are percentages unless otherwise stated

†46 participants did not respond at wave 2; 34 did not respond at wave 1

730 participants did not respond at wave 2; 28 did not respond at wave 1

perceived the risk of COVID-19 or their own susceptibility (Table 5).

\section{COVID-19 Knowledge}

At wave 2, participants estimated significantly higher fatality rates from COVID-19 than in wave 1 (mean (SD) 14.0 (19.3) vs. 15.5 (20.6), $p=0.02$; Table 2). Most participants $(81.6 \%)$ were able to correctly identify 3 symptoms and $74.3 \%$ could name 3 methods of preventing infection. Knowledge of symptoms increased significantly from wave 1 to 2 while knowledge of prevention did not (Table 2). In bivariate analyses, men, individuals with low or marginal health literacy, Englishspeaking adults, and those with multiple chronic conditions had less knowledge of coronavirus symptoms (Table 3). As in wave 1, Hispanic and LEP adults had significantly greater knowledge of methods to prevent coronavirus (Table 4). ${ }^{9}$

After multivariable adjustment, no participant characteristics were significantly associated with knowledge of coronavirus symptoms or prevention. This was consistent with wave 1 findings. ${ }^{9}$ When examining change from wave 1 to wave 2 , individuals who were older, female, black, or with low health literacy skills were more likely 
Table 3 Knowledge, Beliefs, Reported Behaviors, and Perceived Preparedness to COVID-19 Across Sample Characteristics at Wave $2(n=$ 588)*

\begin{tabular}{|c|c|c|c|c|c|c|}
\hline & \multirow{2}{*}{$\begin{array}{l}\text { Perceived susceptibility, } \\
\%\end{array}$} & \multicolumn{2}{|c|}{ Knowledge, \% } & \multicolumn{2}{|c|}{ Reported behaviors, \% } & \multirow{2}{*}{$\begin{array}{l}\text { Perceived preparedness, } \\
\% \\
\text { Not or a little prepared }\end{array}$} \\
\hline & & Symptoms & Prevention & $\begin{array}{l}\text { Changed daily } \\
\text { routine }\end{array}$ & $\begin{array}{l}\text { Changed } \\
\text { plans }\end{array}$ & \\
\hline \multicolumn{7}{|l|}{ Age group } \\
\hline$<60$ years & 21.5 & 81.1 & 78.8 & $76.9 \dagger$ & 86.3 & 21.3 \\
\hline $60-69$ years & 23.6 & 86.1 & 74.4 & $75.4 \ddagger$ & 87.4 & 18.6 \\
\hline$\geq 70$ years & 22.2 & 76.4 & 68.3 & $64.6 \%$ & 83.6 & 22.4 \\
\hline \multicolumn{7}{|l|}{ Sex } \\
\hline Female & $26.2 \dagger$ & $84.7 \dagger$ & 74.2 & 73.9 & $89.2 \dagger$ & 22.4 \\
\hline Male & $16.9 \dagger$ & $77.1+$ & 74.6 & 71.6 & $81.4 \dagger$ & 17.9 \\
\hline \multicolumn{7}{|l|}{ Race } \\
\hline Black & $30.0 \dagger$ & 77.4 & 74.0 & 67.2 & 84.8 & 22.7 \\
\hline White & $17.4 \dagger$ & 84.5 & 74.8 & 75.6 & 87.5 & 19.1 \\
\hline Other & $32.1 \dagger$ & 75.0 & 71.4 & 71.4 & 89.3 & 21.4 \\
\hline \multicolumn{7}{|l|}{ Hispanic } \\
\hline Yes & 26.2 & 82.7 & $82.7 t$ & 74.8 & 86.6 & $35.4 \S$ \\
\hline No & 21.4 & 81.3 & $72.2 \ddagger$ & 72.6 & 86.1 & $16.3 \S$ \\
\hline \multicolumn{7}{|c|}{ Limited English proficiency } \\
\hline Yes & 31.8 & $92.5 t$ & $85.1 t$ & 77.6 & 89.6 & $46.3 \S$ \\
\hline No & 21.2 & $80.2 \div$ & $72.9 \dagger$ & 72.4 & 85.6 & $17.3 \S$ \\
\hline \multicolumn{7}{|c|}{ Below poverty level } \\
\hline Yes & $32.5 \S$ & 84.2 & 74.6 & 73.8 & 88.5 & $27.9 \dagger$ \\
\hline \multirow{2}{*}{\multicolumn{7}{|c|}{ Married** }} \\
\hline & & & & & & \\
\hline Yes & 20.5 & 82.7 & 73.2 & 72.7 & 87.7 & 20.9 \\
\hline \multirow{2}{*}{\multicolumn{7}{|c|}{ Employed }} \\
\hline & & & & & & \\
\hline Yes & $15.2 \dagger$ & 80.9 & 78.7 & $82.0 \S$ & 87.1 & $14.1 t$ \\
\hline No & 25.5 & 82.0 & 72.4 & $69.0 \S$ & 85.6 & 23.4 \\
\hline \multicolumn{7}{|l|}{ Health literacy } \\
\hline Low & $28.6 \S$ & 78.5 & 72.6 & $64.4 \dagger$ & $77.0 \dagger$ & $30.4 \S$ \\
\hline Marginal & $33.3 \S$ & 75.5 & 69.8 & 71.2 & $87.8 \dagger$ & $23.2 \S$ \\
\hline Adequate & $15.0 \S$ & $85.7+$ & 77.1 & $77.4 t$ & $89.2 \dagger$ & $15.3 \S$ \\
\hline \multicolumn{7}{|c|}{ Health activation } \\
\hline Low & 18.6 & 84.5 & 71.7 & 72.8 & 88.0 & $27.0 \S$ \\
\hline Moderate & 24.6 & 79.4 & 77.3 & 72.1 & 85.8 & $16.2 \S$ \\
\hline Adequate & 31.6 & 77.6 & 74.1 & 77.6 & 77.6 & $8.6 \S$ \\
\hline \multicolumn{7}{|c|}{ Number of conditions } \\
\hline $1-2$ & 23.3 & $87.8 \dagger$ & 76.5 & 74.8 & $92.6 \S$ & 21.7 \\
\hline \multirow{2}{*}{\multicolumn{7}{|c|}{ Self-reported health }} \\
\hline & & & & & & \\
\hline $\begin{array}{l}\text { Good to } \\
\text { excellent }\end{array}$ & 22.4 & 82.4 & 75.1 & 74.6 & 86.6 & 19.6 \\
\hline Fair to poor & 22.3 & 78.7 & 71.7 & 66.9 & 84.3 & 24.4 \\
\hline
\end{tabular}

COVID-19 coronavirus disease 2019

*Statistically significant values are shown in bold

$t p<0.01$

$\pm p<0.05$

$\S p<0.001$

to increase their knowledge of coronavirus symptoms; those who lived below the poverty level as well as those above the poverty line also experienced increases in symptom knowledge (Table 5).

\section{COVID-19-Related Behaviors}

At wave $2,73.0 \%$ of participants reported that coronavirus had changed their daily routine "a lot" and $86.0 \%$ stated that they had changed plans due to coronavirus. There was a significant increase in both of these behaviors from waves 1 to 2 (Table 2). Participants who were older, unemployed, and with low health literacy were less likely to report changing their daily routine "a lot" at wave 2 while men, individuals with low health literacy, and adults with three or more chronic conditions were less likely to report changing plans (Table 3).

After multivariable adjustment, there were no participant characteristics that were associated with changes in daily routine or plans at wave 2 . This was consistent with wave $1 .{ }^{9}$ In repeated effect interaction models assessing changes between waves 1 and 2, increased changes in behavior were noted across a number of participant characteristics. Specifically, participants under the age of 70 , both men and women, individuals of both black and white race, those living below and above the poverty line, and those with low, marginal and adequate health literacy experienced either more changes to daily routines or plans or both (Table 5). 
Table 4 Multivariable Models Examining Patient Characteristics and COVID-19 Knowledge, Beliefs, Reported Behaviors, and Perceived Preparedness $(n=546)^{*}$

\begin{tabular}{|c|c|c|c|c|c|c|}
\hline \multirow[t]{2}{*}{ Variable } & \multirow{2}{*}{$\begin{array}{l}\begin{array}{l}\text { Perceived } \\
\text { susceptibility }\end{array} \\
\begin{array}{l}\text { Not likely to get } \\
\text { sick }\end{array}\end{array}$} & \multicolumn{2}{|l|}{ Knowledge } & \multicolumn{2}{|l|}{ Reported behavior } & \multirow{2}{*}{$\begin{array}{l}\text { Preparedness } \\
\begin{array}{l}\text { Not at all or a little } \\
\text { prepared }\end{array}\end{array}$} \\
\hline & & Symptoms & Prevention & $\begin{array}{l}\text { Change in daily } \\
\text { routine }\end{array}$ & $\begin{array}{l}\text { Changed } \\
\text { plans }\end{array}$ & \\
\hline \multicolumn{7}{|l|}{ Age group } \\
\hline$<60$ years & 1.00 (reference) & - & - & - & - & - \\
\hline $60-69$ years & $1.06(0.67-1.69)$ & $\begin{array}{l}1.09(0.87- \\
1.38)\end{array}$ & $\begin{array}{l}0.91(0.72- \\
1.17)\end{array}$ & $1.06(0.81-1.41)$ & $\begin{array}{l}0.99(0.78- \\
1.27)\end{array}$ & $0.74(0.46-1.18)$ \\
\hline$\geq 70$ years & $1.07(0.61-1.88)$ & $\begin{array}{l}0.99(0.74 \\
1.32)\end{array}$ & $\begin{array}{l}0.84(0.62- \\
1.14)\end{array}$ & $0.93(0.66-1.31)$ & $\begin{array}{l}0.98(0.73- \\
1.32)\end{array}$ & $0.94(0.55-1.63)$ \\
\hline \multicolumn{7}{|l|}{ Sex } \\
\hline Female & $1.24(0.83-1.85)$ & $\begin{array}{l}1.11(0.91- \\
1.36)\end{array}$ & $\begin{array}{l}0.98(0.80- \\
1.20)\end{array}$ & $1.04(0.82-1.31)$ & $\begin{array}{l}1.15(0.94- \\
1.41)\end{array}$ & $1.07(0.72-1.59)$ \\
\hline Black & $11.62(1.07-2.44) \ddagger$ & $\begin{array}{l}0.94(0.76- \\
1.17)\end{array}$ & $\begin{array}{l}1.04(0.93- \\
1.30)^{(-)}\end{array}$ & $0.80(0.61-1.04)$ & $\begin{array}{l}0.88(0.70- \\
1.10)\end{array}$ & $1.12(0.73-1.73)$ \\
\hline White & 1.00 (reference) & - & - & - & - & - \\
\hline Other & $1.58(0.77-3.25)$ & $\begin{array}{l}0.93(0.60- \\
1.46)\end{array}$ & $\begin{array}{l}0.99(0.62- \\
1.56)\end{array}$ & $0.96(0.57-1.61)$ & $\begin{array}{l}1.06(0.68- \\
1.63)^{(0-}\end{array}$ & $1.06(0.45-2.50)$ \\
\hline $\begin{array}{l}\text { Below poverty level } \\
\text { Yes }\end{array}$ & $1.45(0.95-2.21)$ & $\begin{array}{l}1.04(0.82- \\
1.31)\end{array}$ & $\begin{array}{l}0.98(0.76- \\
1.25)\end{array}$ & $0.77(0.57-1.04)$ & $\begin{array}{l}0.90(0.71- \\
1.16)\end{array}$ & $1.09(0.69-1.71)$ \\
\hline $\begin{array}{l}\text { No } \\
\text { Health literacy }\end{array}$ & 1.00 (reference) & - & - & - & - & - \\
\hline Low & $1.49(0.90-2.47)$ & $\begin{array}{l}0.90(0.69- \\
1.17)\end{array}$ & $\begin{array}{l}0.92(0.70- \\
1.21)\end{array}$ & $0.75(0.54-1.04)$ & $\begin{array}{l}0.83(0.64 \\
1.10)\end{array}$ & $1.80(1.11-2.92) \ddagger$ \\
\hline Marginal & $1.96(1.26-3.07) \S$ & $\begin{array}{l}0.88(0.70- \\
1.12)\end{array}$ & $\begin{array}{l}0.93(0.72- \\
1.19)^{(2-}\end{array}$ & $0.96(0.73-1.27)$ & $\begin{array}{l}0.90(0.71- \\
1.15)\end{array}$ & $1.33(0.81-2.16)$ \\
\hline Adequate & 1.00 (reference) & - & - & - & - & - \\
\hline $\begin{array}{l}\text { Days between } \\
\text { interviews }\end{array}$ & $1.02(0.93-1.12)$ & $\begin{array}{l}1.02(0.98- \\
1.07)\end{array}$ & $\begin{array}{l}1.01(0.96- \\
1.06)\end{array}$ & $0.93(0.88-0.99) \dagger$ & $\begin{array}{l}0.98(0.93- \\
1.03)^{(-)}\end{array}$ & $0.96(0.87-1.06)$ \\
\hline
\end{tabular}

COVID-19 coronavirus disease 2019

*Model was adjusted for variables in table and parent study. Values are risk ratios (95\% CI) unless otherwise stated. Statistically significant values are in bold

$t p<0.001$

$\pm p<0.05$

$\S p<0.01$

\section{Confidence in the Government and Perceived Preparedness for COVID-19 Outbreak}

Confidence in the federal government's ability to prevent further outbreak did not change significantly between waves and $8.9 \%$ of participants at wave 2 reported that they were "very confident" in the government's response. In multivariate analyses, individuals with low or marginal health literacy were more likely to express that they were "somewhat" or "very" confident in the government (low: relative risk $2.11,95 \% \mathrm{CI}$ 1.49-3.00; $p<0.001$; marginal: relative risk $1.46,95 \% \mathrm{CI}$ $1.04-2.07 ; p=0.03$ ); a similar relationship with low health literacy was found in wave $1 .{ }^{9}$

More than a quarter $(27.3 \%)$ of participants at wave 2 believed they were "very prepared" for the coronavirus outbreak and most $(52.1 \%)$ thought they were "somewhat prepared" while $20.6 \%$ stated they were "a little" or "not prepared at all." There were significant differences in the level of perceived preparedness between waves 1 and 2, with more participants at wave 2 feeling prepared (Table 2). However, similar to wave 1, individuals who were Hispanic, those with limited English proficiency, individuals living below poverty level, the unemployed, those with low or marginal health literacy, and participants with low or moderate health activation were more likely to state that they were "not at all prepared" in bivariate analyses (Table 3).

In multivariable analyses, only individuals with low health literacy were more likely to be "a little" or "not prepared at all" (Table 4). In wave 1, black participants and individuals with low health literacy were more likely to report feeling low preparedness. In regard to change, adults living below the poverty line and those who were black, male, and ages 60-69 were less likely to report being "a little" or "not at all" prepared during the acceleration phase of the US outbreak in comparison to the onset.

\section{DISCUSSION}

Findings from this longitudinal study reveal key changes in adults' knowledge, beliefs, behaviors, and preparedness from the onset of the US outbreak to the acceleration phase. Our results indicate that adults increasingly perceive COVID-19 as a very serious public health threat and made more changes to their daily routine and plans as the pandemic progressed. Importantly, most individuals' perceptions of their own preparedness for the outbreak also increased. These changes are particularly notable among black adults and those living below the poverty level, who at the onset of the pandemic were disproportionately more 
Table 5 COVID-19 Knowledge, Beliefs, Reported Behaviors, and Perceived Preparedness Across Sample Characteristics $(n=588) *$

\begin{tabular}{|c|c|c|c|c|c|c|c|c|c|c|c|c|}
\hline & \multirow{2}{*}{\multicolumn{2}{|c|}{$\begin{array}{l}\begin{array}{l}\text { Perceived } \\
\text { susceptibility, LS } \\
\text { mean (SE) }\end{array} \\
\begin{array}{l}\text { Not at all likely } \\
\text { to get sick }\end{array}\end{array}$}} & \multicolumn{4}{|c|}{ Knowledge, LS mean (SE) } & \multicolumn{4}{|c|}{ Reported behaviors, LS mean (SE) } & \multirow{2}{*}{\multicolumn{2}{|c|}{$\begin{array}{l}\text { Perceived } \\
\text { preparedness, LS } \\
\text { mean (SE) } \\
\text { Not prepared }\end{array}$}} \\
\hline & & & \multicolumn{2}{|c|}{ Symptoms } & \multicolumn{2}{|c|}{ Prevention } & \multicolumn{2}{|c|}{$\begin{array}{l}\text { Changed daily } \\
\text { routine }\end{array}$} & \multicolumn{2}{|c|}{ Changed plans } & & \\
\hline & W1 & W2 & W1 & $\mathbf{W 2}$ & W1 & $\mathbf{W 2}$ & W1 & $\mathbf{W} 2$ & W1 & $\mathbf{W} 2$ & W1 & $\mathbf{W 2}$ \\
\hline \multicolumn{13}{|l|}{ Age group } \\
\hline & 0.26 & 22 & 67 & 0.73 & & & 0.5 & & & & & 0.23 \\
\hline $\mathrm{rg}$ & $(0.05)$ & $.04)$ & $.05)$ & $(0.04)$ & $.04)$ & $(0.04)$ & $(0.05) \S$ & $(0.04) \S$ & $(0.04) \dagger$ & $(0.04) \dagger$ & 4) & $(0.04)$ \\
\hline $60-69$ & 0.24 & 0.25 & 0.71 & 0.84 & .73 & 0.74 & 0.58 & 0.73 & 0.77 & 0.89 & 0.29 & 0.17 \\
\hline years & $(0.04)$ & $(0.04)$ & $(0.04) \dagger$ & $(\mathbf{0 . 0 3}) \dagger$ & $(0.04)$ & $(0.04)$ & $(0.05) \dagger$ & $(0.04) \dagger$ & $(0.04) \dagger$ & $(\mathbf{0 . 0 3}) \dagger$ & $(0.04) \dagger$ & $(\mathbf{0 . 0 3}) \dagger$ \\
\hline$\geq 70$ & 0.32 & 0.27 & 0.59 & 0.74 & 0.63 & 0.70 & 0.50 & 0.5 & 0.76 & 0.82 & 0.27 & 0.22 \\
\hline \multirow{2}{*}{\multicolumn{13}{|c|}{ Sex }} \\
\hline & & & & & & & & & & & & \\
\hline Female & $\begin{array}{l}0.28 \\
(0.04)\end{array}$ & $\begin{array}{l}0.27 \\
(0.04)\end{array}$ & $\begin{array}{l}0.69 \\
(0.04) \S\end{array}$ & $\begin{array}{l}\mathbf{0 . 8 2} \\
(0.03) \S\end{array}$ & $\begin{array}{l}0.71 \\
(0.03)\end{array}$ & $\begin{array}{l}0.74 \\
(0.03)\end{array}$ & $\begin{array}{l}\mathbf{0 . 5 4} \\
(\mathbf{0 . 0 4}) \S\end{array}$ & $\begin{array}{l}0.71 \\
(0.04) \S\end{array}$ & $\begin{array}{l}0.81 \\
(0.03) \dagger\end{array}$ & $\begin{array}{l}0.90 \\
(0.02)\end{array}$ & $\begin{array}{l}0.27 \\
(0.04)\end{array}$ & $\begin{array}{l}0.20 \\
(0.03)\end{array}$ \\
\hline Male & $\begin{array}{l}0.26 \\
(0.04)\end{array}$ & $\begin{array}{l}0.22 \\
(0.04)\end{array}$ & $\begin{array}{l}0.64 \\
(0.04)\end{array}$ & $\begin{array}{l}0.71 \\
(0.04)\end{array}$ & $\begin{array}{l}0.69 \\
(0.04)\end{array}$ & $\begin{array}{l}0.74 \\
(0.04)\end{array}$ & $\begin{array}{l}\mathbf{0 . 5 0} \\
(\mathbf{0 . 0 3}) \dagger\end{array}$ & $\begin{array}{l}0.66 \\
(0.04) \dagger\end{array}$ & $\begin{array}{l}\mathbf{0 . 7 0} \\
(\mathbf{0 . 0 5}) \dagger\end{array}$ & $\begin{array}{l}0.82 \\
(0.04) \dagger\end{array}$ & $\begin{array}{l}0.31 \\
(0.05) \dagger\end{array}$ & $\begin{array}{l}0.20 \\
(\mathbf{0 . 0 4}) \dagger\end{array}$ \\
\hline \multicolumn{13}{|l|}{ Race } \\
\hline Black & $\begin{array}{l}0.37 \\
(0.05)\end{array}$ & $\begin{array}{l}0.30 \\
(0.04)\end{array}$ & $\begin{array}{l}0.64 \\
(0.04) \dagger\end{array}$ & $\begin{array}{l}\mathbf{0 . 7 8} \\
(\mathbf{0 . 0 4}) \dagger\end{array}$ & $\begin{array}{l}0.71 \\
(0.04)\end{array}$ & $\begin{array}{l}0.75 \\
(0.04)\end{array}$ & $\begin{array}{l}0.43 \\
(0.04) \S\end{array}$ & $\begin{array}{l}\mathbf{0 . 6 3} \\
(0.04) \S\end{array}$ & $\begin{array}{l}0.66 \\
(0.05) \S\end{array}$ & $\begin{array}{l}0.83 \\
(0.03) \S\end{array}$ & $\begin{array}{l}0.39 \\
(0.04) \dagger\end{array}$ & $\begin{array}{l}0.22 \\
(\mathbf{0 . 0 4}) \dagger\end{array}$ \\
\hline White & $\begin{array}{l}0.18 \\
(0.03)\end{array}$ & $\begin{array}{l}0.17 \\
(0.03)\end{array}$ & $\begin{array}{l}0.74 \\
(0.03)\end{array}$ & $\begin{array}{l}0.82 \\
(0.02)\end{array}$ & $\begin{array}{l}0.69 \\
(0.03)\end{array}$ & $\begin{array}{l}0.73 \\
(0.03)\end{array}$ & $\begin{array}{l}0.57 \\
(0.03) \S\end{array}$ & $\begin{array}{l}0.72 \\
(0.03) \S\end{array}$ & $\begin{array}{l}\mathbf{0 . 7 8} \\
(\mathbf{0 . 0 3}) \dagger\end{array}$ & $\begin{array}{l}0.86 \\
(0.03) \dagger\end{array}$ & $\begin{array}{l}0.24 \\
(0.03)\end{array}$ & $\begin{array}{l}0.20 \\
(0.030)\end{array}$ \\
\hline Other & $\begin{array}{l}0.29 \\
(0.10)\end{array}$ & $\begin{array}{l}0.29 \\
(0.10)\end{array}$ & $\begin{array}{l}0.54 \\
(0.10)\end{array}$ & $\begin{array}{l}0.77 \\
(0.08)\end{array}$ & $\begin{array}{l}0.72 \\
(0.09)\end{array}$ & $\begin{array}{l}0.72 \\
(0.09)\end{array}$ & $\begin{array}{l}0.56 \\
(0.11)\end{array}$ & $\begin{array}{l}0.72 \\
(0.09)\end{array}$ & $\begin{array}{l}0.82 \\
(0.08)\end{array}$ & $\begin{array}{l}0.90 \\
(0.06)\end{array}$ & $\begin{array}{l}0.21 \\
(0.08)\end{array}$ & $\begin{array}{l}0.21 \\
(0.08)\end{array}$ \\
\hline \multicolumn{13}{|c|}{ Below poverty level } \\
\hline Yes & $\begin{array}{l}0.38 \\
(0.06)\end{array}$ & $\begin{array}{l}0.32 \\
(0.05)\end{array}$ & $\begin{array}{l}\mathbf{0 . 6 2} \\
(0.05) \dagger\end{array}$ & $\begin{array}{l}\mathbf{0 . 8 1} \\
(0.04) \dagger\end{array}$ & $\begin{array}{l}0.75 \\
(0.04)\end{array}$ & $\begin{array}{l}0.71 \\
(0.05)\end{array}$ & $\begin{array}{l}0.42 \\
(0.05) \S\end{array}$ & $\begin{array}{l}0.69 \\
(0.05) \S\end{array}$ & $\begin{array}{l}0.79 \\
(0.03)\end{array}$ & $\begin{array}{l}0.86 \\
(0.03)\end{array}$ & $\begin{array}{l}0.29 \\
(0.05) \dagger\end{array}$ & $\begin{array}{l}0.21 \\
(0.04) \dagger\end{array}$ \\
\hline No & $\begin{array}{l}0.23 \\
(0.03)\end{array}$ & $\begin{array}{l}0.22 \\
(0.03)\end{array}$ & $\begin{array}{l}0.68 \\
(0.04) \ddagger\end{array}$ & $\begin{array}{l}0.76 \\
(0.03) \ddagger\end{array}$ & $\begin{array}{l}0.68 \\
(0.03)\end{array}$ & $\begin{array}{l}0.74 \\
(0.03)\end{array}$ & $\begin{array}{l}0.60 \\
(0.04) \S\end{array}$ & $\begin{array}{l}0.72 \\
(0.03) \S\end{array}$ & $\begin{array}{l}0.71 \\
(0.05) \S\end{array}$ & $\begin{array}{l}0.90 \\
(\mathbf{0 . 0 3}) \S\end{array}$ & $\begin{array}{l}0.27 \\
(0.04)\end{array}$ & $\begin{array}{l}0.19 \\
(0.03)\end{array}$ \\
\hline \multicolumn{13}{|c|}{ Health literacy } \\
\hline Low & $\begin{array}{l}0.37 \\
(0.06)\end{array}$ & $\begin{array}{l}0.24 \\
(0.05)\end{array}$ & $\begin{array}{l}0.53 \\
(0.05) \S\end{array}$ & $\begin{array}{l}0.77 \\
(\mathbf{0 . 0 4}) \S\end{array}$ & $\begin{array}{l}0.73 \\
(0.05)\end{array}$ & $\begin{array}{l}0.70 \\
(0.05)\end{array}$ & $\begin{array}{l}0.41 \\
(0.05) \S\end{array}$ & $\begin{array}{l}0.63 \\
(0.05) \S\end{array}$ & $\begin{array}{l}0.67 \\
(0.06)\end{array}$ & $\begin{array}{l}0.79 \\
(0.05)\end{array}$ & $\begin{array}{l}0.39 \\
(0.05)\end{array}$ & $\begin{array}{l}0.27 \\
(0.05)\end{array}$ \\
\hline Marginal & $\begin{array}{l}0.29 \\
(0.05)\end{array}$ & $\begin{array}{l}0.34 \\
(0.06)\end{array}$ & $\begin{array}{l}0.68 \\
(0.05)\end{array}$ & $\begin{array}{l}0.73 \\
(0.05)\end{array}$ & $\begin{array}{l}0.69 \\
(0.05)\end{array}$ & $\begin{array}{l}0.71 \\
(0.05)\end{array}$ & $\begin{array}{l}0.56 \\
(0.06)\end{array}$ & $\begin{array}{l}0.70 \\
(0.05)\end{array}$ & $\begin{array}{l}0.74 \\
(0.05) \dagger\end{array}$ & $\begin{array}{l}0.88 \\
(0.03) \dagger\end{array}$ & $\begin{array}{l}0.28 \\
(0.05)\end{array}$ & $\begin{array}{l}0.20 \\
(0.04)\end{array}$ \\
\hline Adequate & $\begin{array}{l}0.18 \\
(0.03)\end{array}$ & $\begin{array}{l}0.17 \\
(0.03)\end{array}$ & $\begin{array}{l}0.74 \\
(0.04)\end{array}$ & $\begin{array}{l}0.83 \\
(0.03)\end{array}$ & $\begin{array}{l}0.71 \\
(0.04)\end{array}$ & $\begin{array}{l}0.78 \\
(0.03)\end{array}$ & $\begin{array}{l}0.59 \\
(0.05) \S\end{array}$ & $\begin{array}{l}0.74 \\
(0.04) \S\end{array}$ & $\begin{array}{l}0.85 \\
(0.03)\end{array}$ & $\begin{array}{l}0.91 \\
(0.02) \ddagger\end{array}$ & $\begin{array}{l}0.20 \\
(0.03)\end{array}$ & $\begin{array}{l}0.15 \\
(0.03)\end{array}$ \\
\hline
\end{tabular}

COVID-19 coronavirus disease 2019

*Statistically significant interactions between a wave and category of a covariate are shown in bold. Post hoc paired test p-value less than Bonferroni adjusted significance level

$t p<0.01$

$\neq p<0025$

$\S p<0.001$

likely to feel unprepared. Participants' ability to identify COVID19 symptoms improved over time.

Despite these positive developments, serious public health concerns remain. Participants with low health literacy continue to be more likely to report feeling unprepared for the outbreak and 1 in 4 of these high-risk adults was unable to accurately identify methods of preventing COVID-19, a proportion that was unchanged since the onset of the pandemic. Additionally, almost a quarter of participants - who are predominately older, with multiple underlying health conditions - reported believing that it was "not at all likely" that they would become sick from the coronavirus. Black adults and those with lower health literacy continued to be more likely to have lower perceived susceptibility.

The C3 study has provided a unique opportunity to understand how high-risk adults' knowledge, beliefs, behaviors, and preparedness changed over the initial stages of a pandemic. Wave 1 was conducted at the onset of the US outbreak, when the number of cases of COVID-19 in Illinois ranged from 46 to 585 and no "stay at home" order had been issued. ${ }^{17}$ In contrast, during wave 2, there were between 3026 and 13,549 cases in Illinois and all state residents had been ordered to stay home. ${ }^{17}$ Unsurprisingly, there was a marked shift in participants' daily routines between waves 1 and 2 and increased recognition of the public health threat posed by COVID-19.

Yet, our findings also reveal clear differences in how adults perceive their own individual risk for COVID-19, their sense of preparedness for the outbreak, and their knowledge of what can be done to prevent infection. These findings suggest that public health messages on risk factors for coronavirus, its potential spread, and methods of preventing COVID-19 are not reaching all Americans, particularly the most vulnerable. Misinformation on effective methods of prevention are widespread and may be contributing to poorer understanding of how to effectively reduce transmission of the virus. ${ }^{18,} 19$ Individuals with low health literacy, who are likely to struggle to obtain, process, and understand public health messages related to COVID-19, are more likely to feel unprepared for the pandemic and to perceive themselves as less susceptible to COVID-19, which may place them at greater risk. ${ }^{7,20}$ 
This study has limitations. Participants were predominately older, most had three or more chronic conditions, and all lived in metro Chicago, IL. As such, findings may not be generalizable to younger or healthier adults or to individuals in other geographic locations. Findings indicate that adults' knowledge, beliefs, behaviors, and preparedness changed over time with the pandemic; as such, results from this wave may not be reflective of current norms by the time of publication. However, our team is mobilizing to conduct additional waves of this study at future dates. Finally, this study relied upon self-report measures. It is possible that social desirability bias may have led participants to over-report changes to their behaviors. However, given the restrictions currently in place in Illinois, it is likely changes in daily routines and plans occurred for most participants.

Our first longitudinal assessment of the $\mathrm{C} 3$ study revealed that participants increasingly perceived COVID-19 to be a serious public health threat, reported more changes to their daily routine and plans, and had a greater sense of preparedness from the onset to the acceleration phase of the outbreak. Yet, knowledge deficits remain and many high-risk participants still perceived themselves as being "not at all likely" to become sick even after cases had greatly increased in the region. Accurate, easy-to-understand, and consistent public health messaging that can reach all Americans, including the most at risk and vulnerable, is needed to reduce the threat posed by the COVID-19 outbreak and to ensure that everyone is prepared and aware of the actions that can be taken to protect themselves, their families, and their communities from this rapidly evolving public health crisis.

Data Availability: The datasets generated during and/or analyzed during the current study are available from the corresponding author upon reasonable request.

Corresponding Author: Stacy Cooper Bailey, PhD MPH; Division of General Internal Medicine \& Geriatrics, Feinberg School of Medicine at Northwestern University, 750 N. Lake Shore Drive, 10th Floor, Chicago, IL 60611, USA (e-mail: stacy-bailey@northwestern.edu).

Funding Information This work was supported by grants R01AG030611, R01AG046352, RO1DK110172, and R01NR01544 from the National Institutes of Health (NIH). Dr. Linder is supported by a contract from the Agency for Healthcare Research and Buality (HHSP233201500020I) and by grants from the National Institute on Aging (R33AG057383, R33AG057395, P30AG059988), the Agency for Healthcare Research and Quality (R01HS026506), and the Peterson Center on Healthcare.

\section{Compliance with Ethical Standards:}

The Northwestern Institutional Review Board (IRB) approved the study procedures.

Conflict of Interest: Dr. Bailey reports grants from the NIH, Merck, Pfizer, the Gordon and Betty Moore Foundation, and Eli Lilly and personal fees from the Gordon and Betty Moore Foundation, Sanofi, Pfizer, and Luto outside the submitted work. Dr. Serper reports personal fees from BioVie outside the submitted work. Ms. Batio reports grants from the NIH during the conduct of the study. Dr. Ladner reports grants from the National Institute of Diabetes and Digestive and Kidney Diseases during the conduct of the study. Dr. Persell reports grants from Omron Healthcare and Pfizer outside the submitted work. Dr. Wolf reports grants from the NIH during the conduct of the study; grants from Merck, the Gordon and Betty Moore
Foundation, the NIH, and Eli Lilly outside the submitted work; and personal fees from Sanofi, Pfizer, and Luto outside the submitted work. Authors not named here have disclosed no conflicts of interest.

\section{REFERENCES}

1. Vaughan E, Tinker T. Effective health risk communication about pandemic influenza for vulnerable populations. Am J Public Health. 2009;99 Suppl 2:S324-32.

2. Garg S, Kim L, Whitaker M, et al. Hospitalization rates and characteristics of patients hospitalized with laboratory-confirmed Coronavirus Disease 2019 - COVID-NET, 14 states, March 1-30, 2020. MMWR Morb Mortal Weekly Rep. 8 April 2020. Accessed at https://www.cdc.gov/ mmwr/volumes/69/wr/mm6915e3.htm on 12 April 2020.

3. Latest Data: COVID-19. City of Chicago. Accessed at www.chicago.gov/ city/en/sites/covid-19/home/latest-data.html on 12 April 2020.

4. Reynolds B, Quinn Crouse S. Effective communication during an influenza pandemic: the value of using a crisis and emergency risk communication framework. Health Promot Pract. 2008;9(4 Suppl):13s7s.

5. Hutchins SS, Truman BI, Merlin TL, Redd SC. Protecting vulnerable populations from pandemic influenza in the United States: a strategic imperative. Am J Public Health. 2009;99 Suppl 2:S243-8.

6. Blendon RJ, Koonin LM, Benson JM, et al. Public response to community mitigation measures for pandemic influenza. Emerg Infect Dis. 2008 ; $14(5): 778-86$.

7. Institute of Medicine. Health literacy: A prescription to end confusion. Washington DC: National Academy Press; 2004.

8. Bish A, Michie S. Demographic and attitudinal determinants of protective behaviours during a pandemic: a review. Br J Health Psychol. 2010;15(Pt 4):797-824.

9. Wolf MS, Serper M, Opsasnick L, et al. Awareness, attitudes, and actions related to COVID-19 among adults with chronic conditions at the onset of the U.S. outbreak: A cross-sectional survey. Annals of Internal Medicine. 2020.

10. Coronavirus Disease 2019. Atlanta: Centers for Disease Control and Prevention. Accessed at: www.cdc.gov/coronavirus/2019-ncov/casesupdates/cases-in-us.html\#cumulative on 11 April 2020.

11. Mervosh S, Lu D, Swales V. See which states and cities have told residents to stay at home. New York Times. 2020 Apr 7. Accessed at www. nytimes.com/interactive/2020/us/coronavirus-stay-at-home-order.html on 9 April 2020.

12. O'Conor R, Arvanitis M, Wismer G, et al. Rationale and design of the regimen education and messaging in diabetes (REMinD) trial. Contemp Clin Trials. 2019;83:46-52.

13. Bailey SC, Wismer GA, Parker RM, et al. Development and rationale for a multifactorial, randomized controlled trial to test strategies to promote adherence to complex drug regimens among older adults. Contemp Clin Trials. 2017;62:21-6.

14. Wolf MS, Curtis LM, Wilson EA, et al. Literacy, cognitive function, and health: Results of the LitCog Study. Journal of General Internal Medicine. 2012;27(10): 1300-7.

15. Weiss BD, Mays MZ, Martz W, et al. Quick assessment of literacy in primary care: the newest vital sign. Annals of Family Medicine. 2005;3:514-22.

16. Wolf MS, Smith SG, Pandit AU, et al. Development and validation of the Consumer Health Activation Index. Med Decis Making. 2018;38(3):33443.

17. Coronavirus Disease 2019. Springfield: Illinois Department of Public Health. Accessed at: www.dph.illinois.gov/covid19 on 11 April 2020.

18. Breslow $\mathbf{J}$. Why misinformation and distrust are making COVID-19 more dangerous for black America. National Public Radio (NPR) 2020 Apr 10. Accessed at www.npr.org/sections/coronavirus-live-updates/2020/04/ 10/832039813/why-misinformation-and-distrust-is-making-covid-19more-dangerous-for-black-amer on 12 April 2020.

19. Brennan JS, Simon F, Howard PN, Nielsen RK. Types, sources, and claims of COVID-19 misinformation. Oxford, United Kingdon: Reuters Institute for the Study of Journalism. Accessed at reutersinstitute.politics.ox.ac.uk/types-sources-and-claims-covid-19misinformation on 11 April 2020.

20. Gazmararian JA, Curran JW, Parker RM, Bernhardt JM, DeBuono BA. Public health literacy in America: an ethical imperative. Am J Prev Med. 2005;28(3):317-22.

Publisher's Note: Springer Nature remains neutral with regard to jurisdictional claims in published maps and institutional affiliations. 